\title{
CONSUMER PREFERENCES FOR PAWPAW IN IBADAN METROPOLIS
}

\author{
Olabode I.A., Akinwumi G.S., Layade A.A., Adegbite O.O., Researchers \\ National Horticultural Research Institute, Ibadan, Nigeria \\ E-mail: isacola767@yahoo.com, gbenakinwumi@yahoo.com, jumlay408@gmail.com, \\ olayinkadegbite@gmail.com
}

\begin{abstract}
Pawpaw is one of the tropical fruits that are produced and consumed in various forms all through the year in Nigeria. A field research survey was undertaken to study the consumer preference and analyze consumer behaviour regarding pawpaw in Ibadan, Oyo State Nigeria, during the period of June to November 2013. Two hundred and fifty consumers were selected in the metropolis at random for the interview using structured questionnaires. Data were analyzed using descriptive statistics and chi-square. The result of the analysis showed that $52 \%$ of the respondents were female while $48 \%$ were male. Most of the respondents were between 25 and 44 years (68.4\%) and married (74.8\%). Study revealed $65.6 \%$ consumed pawpaw in both peak and lean seasons attributing their reasons to health benefits $>$ taste $>$ colour $>$ price. Preferred attributes of pawpaw include: oblong shape (36.4\%), medium size $(41.2 \%)$, yellow flesh colour $(53.6 \%)$ and slightly green fruit colour $(41.2 \%)$. The chisquare values showed that there was no significant difference in the response on shape ( $p>0.05$ ). However, responses about size, flesh colour, fruit colour and amount willing to pay differ significantly $(p<0.05)$. Factors such as taste $>$ price $>$ size $>$ colour $>$ shape determine purchase decision of pawpaw. The study recommends intensive research into development and multiplication of pawpaw varieties that have appealing characteristics to consumers for increased demand.
\end{abstract}

\section{KEY WORDS}

Consumer preference, characteristics, purchase decision, chi-square.

Pawpaw (Carica papaya L.) is one of the major fruits produced and consumed in Nigeria. The fruit is a power house of nutrients (Nguyen, 2014) which can be consumed as a fresh fruit, processed or used in variety products such as jams, fruit juices and ice cream. Unripe fruits and leaves are consumed as vegetable. The seeds are also used as an ingredient in salad dressings. The fruit is not just delicious and healthy, but whole plant parts, fruit, roots, bark, peel, seeds and pulp are also known to have medicinal properties. The many benefits of papaya owed due to high content of vitamins $A, B$ and $C$, proteolytic enzymes like papain and chymopapain which have antiviral, antifungal and antibacterial properties (Aravind et al, 2013). Its nutritional and industrial utilization potential made it to gain wide acceptance and thus regarded as an important food crop in the tropics (Olubode et al, 2005).

The pawpaw fruit is produced on herbaceous trees grown from seeds, one of the few that bear fruits within a year of planting. Native to Central America and southern Mexico, pawpaw plants can grow more than 30 feet tall on a single trunk (Thomas, 2015). The fruit prefer wind-protected areas with full sun, hot humid climates, well drained soil, regular watering, and steady applications of various fertilizers. Under favorable conditions, plants keep producing fruit throughout the year. Nigeria ranked fifth in Pawpaw production after India, Brazil, Indonesia and Dominican Republic with a production figure of about 775,000 tons (FAOSTAT, 2012). While crop yields vary with plant care and growing conditions, pawpaw, when harvested is green with a stripe of yellow at their base; they ripen during transportation or are commercially ripened on arrival (FAO, 2003). As pawpaw ripens, skin colour changes from green to yellow, and the fruit becomes softer and develops a fruity aroma. Pawpaw is normally sold to consumers when they are at least one-quarter ripe. Optimal ripeness occurs at the three quarter stage, when the fruit bears a yellow-orange peel and an orange-red pulp. Peel colour may vary from yellow to reddish-orange, depending on the variety of pawpaw (FAO, 2003). 
In recent years, Ibadan have seen a rapid change in its citizens' consumptive behaviors and life styles due to economic growth, improvement in the standard of living and fast urbanization. The transitioning economy, the new class of consumers and the change in the food retail sector has added to the change in consumer behavior and consumption preferences. Particularly, the demand for pawpaw, an important component of the lbadan diet, has also been changing in recent years. Preference for fruit size varies for different regions of the world. While the Asian Pacific Region prefers the smaller export size fruit, the Caribbean and Mexican region tend to select the larger fruits above $1 \mathrm{~kg}$ (Nakasone and Paull, 1998). Consumer behaviour research enables better understanding and forecasting not only of the subject of purchases but also of purchasing motives and purchasing frequency (Schiffman, Kanuk 2004). Market prospects for the fruit look bright with growing demand especially in domestic markets because of its health benefits. Understanding consumer preferences and behaviour is important in the related decision-making of key stakeholders, including producers. The purpose of this study therefore is to:

i. Describe the socioeconomic characteristics of respondents.

ii. Assess the pawpaw characteristics that are important to consumers

iii. Identify factors that determine consumer preference for pawpaw as well as influence purchase decision.

\section{METHODOLOGY}

Study area. Ibadan is one of the metropolitan cities in Nigeria. It is the capital city of Oyo state and is located in the South Eastern part of the state. Its population according to 2006 census results was 2,559,853 and it is made up of eleven local government areas (NBS, 2009). The city covers an area of about 3,080 square kilometers (1,190 sq mi) and lies at latitude $7^{\circ} 23^{\prime} 47^{\prime \prime} \mathrm{N}$ and longitude $3^{\circ} 56^{\prime} \mathrm{O}^{\prime \prime} \mathrm{E}$. The field research survey was undertaken to study the consumer preference for pawpaw in Ibadan, Oyo State Nigeria, between June and November 2013. Random sampling technique was adopted in selecting 310 consumers in the metropolis. However, 250 were usable - resulting in a usable response rate of approximately 80.6 percent. Primary data were collected through the use of structured questionnaires. Data collected were on age, educational level, occupation and income. Others includes, information on consumption pattern, fruit physical characteristics, season of consumption, reasons for consumption, frequency of consumption, and other factors that determine the choice of pawpaw. Data were analyzed using descriptive statistics and chisquare.

\section{RESULTS AND DISCUSSION}

Socio-economic characteristics of respondents. Results (Table 1) revealed $52 \%$ of the respondents were female between the ages of 25 and 44 years and married $(74.8 \%)$. This implied that married women who were in their physically/ psychologically active age could positively influence preferences and purchase decisions for pawpaw. Most of the respondents $(64.4 \%)$ had secondary and tertiary education while $64.4 \%$ were civil servant, indicating that most of the respondents were literate and could appreciate the importance of fruit consumption. This is similar to the findings of Ohen et al, (2014), who conducted a study on consumer purchasing behaviour for fruits and vegetables among Civil servants in Essien Udim Local Government Area, Akwa lbom State, Nigeria. Monthly income of most of the

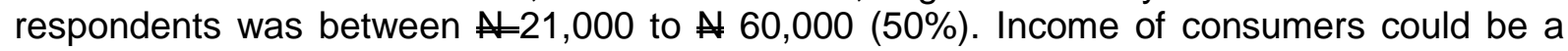
major determinant in the frequency of fruits purchase.

Season and frequency of consumption. Most of the agricultural crops are seasonal and seasonality affects volumes of fruits purchased or consumed significantly (SDC, 2010 and Layade and Adeoye, 2012). About 3.0\% consumed pawpaw during off-season, 31.6\% consumed the fruit at peak season while, majority (65.6\%) of the respondents consumed it in both seasons. This is an indication that seasonality does not affect pawpaw consumption and there is demand for the fruit all through the year. On the basis of frequency of consumption, 
$31.6 \% \%$ consumed pawpaw two to three times per week, $30 \%$ consumed the fruit three to four times per month, while $18.4 \%$ rarely eat pawpaw. Furthermore respondents reported that pawpaw was consumed due to the following reasons: health benefit $>$ taste $>$ colour $>$ price (Table 2).

Table 1 - Socio-economic characteristics of respondents

\begin{tabular}{|c|c|c|}
\hline$n / n$ & Frequency & Percentage \\
\hline \multicolumn{3}{|l|}{ Gender } \\
\hline Male & 120 & 48.0 \\
\hline Female & 130 & 52.0 \\
\hline \multicolumn{3}{|l|}{ Age (years) } \\
\hline $15-24$ & 19 & 7.6 \\
\hline $25-34$ & 84 & 33.6 \\
\hline $35-44$ & 87 & 34.8 \\
\hline $45-54$ & 39 & 15.6 \\
\hline $55-64$ & 7 & 2.8 \\
\hline No response & 14 & 5.6 \\
\hline \multicolumn{3}{|l|}{ Marital status } \\
\hline Single & 63 & 25.2 \\
\hline Married & 187 & 74.8 \\
\hline \multicolumn{3}{|l|}{ Educational level } \\
\hline No formal education & 37 & 14.8 \\
\hline Primary education & 52 & 20.8 \\
\hline Secondary education & 70 & 28.0 \\
\hline Tertiary education & 91 & 36.4 \\
\hline \multicolumn{3}{|l|}{ Occupation } \\
\hline Self employed & 50 & 20.0 \\
\hline Civil servant & 161 & 64.4 \\
\hline Corporate/private organisation & 32 & 12.8 \\
\hline No response & 7 & 2.8 \\
\hline \multicolumn{3}{|l|}{ Monthly Income (A) } \\
\hline$\leq 20000$ & 55 & 22.0 \\
\hline $21000-40000$ & 77 & 30.8 \\
\hline $41000-60000$ & 48 & 19.2 \\
\hline $61000-80000$ & 10 & 4.0 \\
\hline$>80000$ & 19 & 7.6 \\
\hline Above 100000 & 34 & 13.6 \\
\hline No response & 7 & 2.8 \\
\hline
\end{tabular}

Source: Field survey, 2013.

Table 2 - Season and frequency of consumption

\begin{tabular}{|l|l|l|}
\hline \multicolumn{1}{|c|}{ Season } & \multicolumn{1}{c|}{ Frequency } & \multicolumn{1}{c|}{ Percentage } \\
\hline Peak season & 79 & 31.6 \\
\hline Off-season & 7 & 2.8 \\
\hline Both seasons & \multicolumn{2}{l|}{} \\
\hline Frequency of consumption & 164 & 65.6 \\
\hline Rarely (once or less than once in a month) & \multicolumn{2}{l|}{} \\
\hline Occasionally (3-4 times per month) & \multicolumn{2}{l|}{18.4} \\
\hline Regularly (2-3 times per week) & 75 & 30.0 \\
\hline Frequently (once per day) & 79 & 31.6 \\
\hline Reason & 50 & 20.0 \\
\hline Health and nutritional benefits & Yes & No \\
\hline Taste & $231(92.4)$ & $19(7.6)$ \\
\hline Colour & $202(80.8)$ & $48(19.2)$ \\
\hline Price & $154(61.6)$ & $96(38.4)$ \\
\hline
\end{tabular}

Source: Field survey, 2013. Figures in bracket are percentages.

Preferred characteristics of pawpaw. In Table 3, 36.4\% of the respondents preferred oblong shape, followed by round shape $31.6 \%$ and $26.0 \%$ preferred pear shape. $41.2 \%$ preferred medium size while small size of pawpaw was preferred by $16.4 \%$. The medium size 
pawpaw may be preferred as against the big fruit probably because the big fruit tend to have undesirable characteristics as lower fruit number per plant, lower percentage total soluble solid (sweetness) and lack firmness as stated by (Subhadrabandhu et al, 1989). Large fruit size may also be perceived as being produced using hormones. However, the preferred commercial export variety of pawpaw produce fruit is about $400 \mathrm{~g}$. Great effort has gone into developing the multiple small fruited 'Solo lines' of papaya, which are the standard in the export market this is according to (Subhadrabandhu and Nontaswatsri, 1997). In the study areas, consumers do not consider sweetness as a quality attribute since, according to them, consumers are attracted to only good-looking fruit.

On the basis of flesh colour, a significant proportion $53.6 \%$ preferred yellow colour. Color has consistently been an important attribute in previous fruit and vegetable analyses. The relative importance for colour of apples was $17.98 \%$ in Jerko and Kovačić (2008).

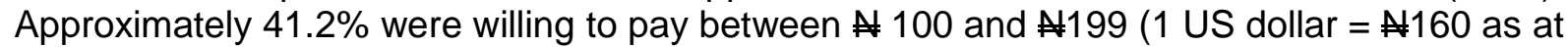
the time of survey). The chi-square values showed that there is no significant different in the response on shape ( $p>0.05)$. The responses about size, flesh colour, fruit colour and willing amount differ significantly $(\mathrm{p}<0.05)$.

Table 3 - Preferred characteristics of pawpaw by respondents

\begin{tabular}{|c|c|c|c|}
\hline $\mathrm{n} / \mathrm{n}$ & Frequency & Percentage & p-value \\
\hline Shape & & & \multirow{5}{*}{0.395} \\
\hline Oblong & 91 & 36.4 & \\
\hline Round & 79 & 31.6 & \\
\hline Pear shape & 65 & 26.0 & \\
\hline No response & 15 & 6.0 & \\
\hline \multicolumn{3}{|l|}{ Size } & \multirow{5}{*}{0.001} \\
\hline Small & 41 & 16.4 & \\
\hline Medium & 103 & 41.2 & \\
\hline Big & 89 & 35.6 & \\
\hline No response & 17 & 6.8 & \\
\hline \multicolumn{3}{|l|}{ Flesh colour } & \multirow{5}{*}{0.001} \\
\hline Pink & 50 & 20.0 & \\
\hline Yellow & 134 & 53.6 & \\
\hline Orange & 39 & 15.6 & \\
\hline Red & 27 & 10.8 & \\
\hline \multicolumn{3}{|l|}{ Fruit colour } & \multirow{5}{*}{0.001} \\
\hline When it is green & 29 & 11.6 & \\
\hline When it is slightly green & 103 & 41.2 & \\
\hline When it is slightly yellow & 101 & 40.4 & \\
\hline When it is very yellow & 17 & 6.8 & \\
\hline \multicolumn{3}{|l|}{ Willing amount to pay ( $\mathbb{A}$ ) } & \multirow{7}{*}{0.001} \\
\hline Less than 100 & 22 & 8.8 & \\
\hline $100-199$ & 103 & 41.2 & \\
\hline $200-299$ & 63 & 25.2 & \\
\hline $300-399$ & 13 & 5.2 & \\
\hline $400-499$ & - & - & \\
\hline 500 and above & 7 & 2.8 & \\
\hline
\end{tabular}

Source: Field survey, 2013.

The major source of pawpaw purchase was the market $(66.0 \%), 23 \%$ from street hawkers, $10 \%$ from farm and only $1 \%$ from grocery stores. This supports the findings of Ohen et al (2014), who reported that most civil servants, who were fruit and vegetable consumers, preferred purchases in an open market reason being that it is readily available or nearer to their residence.

Forms in which the respondents prefer pawpaw. Fresh pawpaw was significantly preferred by the respondents (mean=3.6), followed by fruit salad (mean=1.25) and juice (mean=1.16) (Table 4). 
Table 4 - Forms in which the respondents prefer pawpaw

\begin{tabular}{|l|l|l|l|l|l|l|}
\hline \multicolumn{1}{|c|}{$\mathrm{n} / \mathrm{n}$} & \multicolumn{1}{c|}{ Very important } & \multicolumn{1}{c|}{ Somewhat important } & Important & Less important & Mean & Mean Rank \\
\hline Fresh fruit & $197(78.8)$ & $15(6.0)$ & $26(10.4)$ & $12(4.8)$ & 3.61 & $1 \mathrm{st}$ \\
\hline Juice & $46(18.4)$ & $50(20.0)$ & $48(19.2)$ & $106(42.4)$ & 1.16 & $3 \mathrm{rd}$ \\
\hline Fruit salad & $75(30.0)$ & $48(19.2)$ & $38(15.2)$ & $89(35.6)$ & 1.25 & 2nd \\
\hline
\end{tabular}

Source: Field survey, 2013.

Factors that determine the choice of pawpaw. Taste, price, size, colour and shape were highlighted by respondents as factors that determine their choice of pawpaw in order of importance (Table 5). This supports the report of SDC, (2010), that amongst factors influencing choice of purchase of fruit and vegetables, priority is given to freshness, price, external look/appearance and taste (SDC, 2010).

Table 5 - Factors that determine the choice of pawpaw

\begin{tabular}{|l|l|l|l|l|l|l|}
\hline \multicolumn{1}{|c|}{$\mathrm{n} / \mathrm{n}$} & \multicolumn{1}{|c|}{ Very important } & \multicolumn{1}{c|}{ Somewhat important } & \multicolumn{1}{c|}{ Important } & Less important & Mean & \multicolumn{1}{c|}{ Mean rank } \\
\hline Price & $142(56.8)$ & $27(10.8)$ & $28(11.2)$ & $53(21.2)$ & 3.05 & 2 nd \\
\hline Size & $101(40.4)$ & $46(18.4)$ & $46(18.4)$ & $57(22.8)$ & 2.78 & 3 rd \\
\hline Shape & $82(32.8)$ & $38(15.2)$ & $46(18.4)$ & $84(33.6)$ & 2.49 & 5 th \\
\hline Taste & $178(71.2)$ & $27(10.8)$ & $30(12.0)$ & $15(6.0)$ & 3.50 & $1 \mathrm{st}$ \\
\hline Colour & $101(40.4)$ & $41(16.3)$ & $43(17.3)$ & $65(26.0)$ & 2.73 & 4 th \\
\hline
\end{tabular}

Source: Field survey, 2013.

\section{CONCLUSION}

Changes in the economy have led to changes in consumer behaviour and preferences. Understanding consumer preferences for pawpaw is important for government, policy makers and other stakeholders in the production and marketing of this fruit. These preferences can be determined through the characteristics of the pawpaw product, and consumer types can be inferred from the choices that they make among those attributes. The fact that pawpaw fruit is consumed in both peak and lean seasons with consumers attributing their reasons to health benefits, taste, colour and price necessitates increased production and marketing for year round availability. In order to cope with increasing demand, changing lifestyle and consumer preference, there is the need for intensive research into development and multiplication of pawpaw varieties that have appealing attributes to consumers.

\section{REFERENCES}

1. Aravind G, Bhowmik D, Duraivel S, Harish G. (2013). Traditional and medicinal uses of Carica papaya. Journal of Medicinal Plants Studies.1(1):7-15.

2. Food and Agricultural Organization of the United Nations(2003). Papaya: Post harvest operations.

http://www.fao.org/fileadmin/user_upload/inpho/docs/Post_Harvest_Compendium_Pawpaw_Papaya_pdf. [Online] Assessed: 19th February, 2015.

3. $\overline{F A O S T A T, ~(2012) . ~ P a p a y a ~ P r o d u c t i o n . ~ h t t p: / / f a o s t a t . f a o . o r g / s i t e / 576 / d e f a u l t . a s p . ~[O n l i n e] ~}$ Assessed: 19th February, 2015.

4. Jerko, M., and D. Kovačić. 2008. The importance of apple attributes: a comparison of self-explicated and conjoint analysis results. Paper prepared for presentation at the 12th EAAE congress: "People, Food and Environments: Global Trends and European Strategies", Gent (Belgium), 26-29 August 2008.

5. Layade, A.A and Adeoye, I.B. (2012). Assessment of fruit consumption among students of tertiary institutions in Oyo state. In Proceedings of the 30th Annual conference of Horticultural Society of Nigeria (HORTSON), held at Federal University of Technology, Owerri, Nigeria, 11-15th, 2012. Pp 270-275. Edited by Obiefuna J., Ofoh, M.C, Agu, C.M, Ogoke, I.J, Ngwuta, A.A, Obilo, O.P and Ojiako, F.O. 
6. Nakasone, H.Y. and Paull, R.E. (1998). Tropical Fruits. CAB International, New York Smith, N.J.H.,

7. Nguyen, P.H. (2014). Saccharomyces sp. isolation and comparison of yeast growth between Saccharomyces sp. And Saccharomyces cerevisiae for papaya wine fermentation. International Journal of Multidisciplinary Research and Development 1(5): 99-104.

8. Ohen,, S. B., Umeze, G. E. and Inyang, E.O. (2014). Consumer purchasing behaviour for fruits and vegetables among civil servants in Essien Udim Local Government Area, Akwa Ibom State, Nigeria. Food Science and Quality Management. Vol 23: 55-64. ISSN 22246088 (Paper) ISSN 2225-0557 (Online). http://www.iiste.org

9. Olubode, O.O. Aiyelaagbe, I.O.O. Bodunde, J.G. and Olasantan, F.O. (2005). Growth and yield responses of Pawpaw (Carica papaya L.) varieties to intercropping with vegetables in organic farming system. In Proceedings of the 1st National Conference on Organic Agriculture, UNAAB, Abeokuta, Nigeria, 25-28 October, 2005. pp: 126-131.

10. Schiffman L.G., Kanuk L. (2004). Nákupní chování (Purchasing behaviour). Computer Press, Brno; ISBN 80-251-0094-4.

11. Subhadrabandu, S., Suneru, T. and Dhanasobhon, C. (1989). Improvement of Thai papaya varieties for commercial purposes. Proc. 6th Internal. Congr. of SABRAO. Pp. 677680.

12. Subhadrabandu, S. and Nontaswatsri, C. (1997). Combining ability of some characteristics of introduced and local papaya cultivars. Scientia Horticulturae 71:203212.

13. Swiss Agency for Development and Cooperation (SDC), (2010). Consumption habits and purchasing behaviour survey report. Armenia Markets 4 Meghri Inception phase (January - September 2010).

14. Thomas, C, (2015). Papaya tree fertilizer. http://www.ehow.com/about_6554318_papayatree-fertilizer.html. [Online] Assessed: 19, February, 2015. 